\title{
Legal Protection For Citizens Whose Land Is Exposed To Green Open Space In The Perspective Of Investment In Denpasar City
}

\author{
I Wayan Rideng; I Made Deny Lesmana; I Ketut Widia \\ Magister of Law, Postgraduate Program Warmadewa University, Denpasar, Bali
}

\begin{abstract}
Green Open Space (GOP) is essentially one of the elements of urban space that has the same important role with other elements of the city. The importance of Green Open Space function made the government set a rule in the spatial planning law which states that every city must have Green Open House, a minimum of 30 percent of its city area that consists of 10 percent private Green Open Space which is privately owned GOS and 20 percent of public green space owned by the general public and managed by the government, in accordance with the content of Article 29 paragraph (2) of Law Number 26 of 2007 concerning Spatial Planning. This study aims to find out and to figure out the form of legal protection for citizens whose land is exposed to Green Open Space Areas in Denpasar city and the economic rights granted by Denpasar City Government to the citizens whose land is exposed to the Green Open Space Area. This study is analyzed qualitatively. The empirical legal research or called as sociological legal research is used as the approach of this study. Thus the result of the study showed that there is no form of legal protection provided to people whose lands are exposed to green open space. All forms of people's rights and obligations should be given to the land exposed to the green open space. In this case, what is meant is compensation money in a reasonable amount because people have felt disadvantaged with the green open space policy by Denpasar City Government.
\end{abstract}

Keywords: Arrangement, Green Open Space, Denpasar City

\section{Introduction}

Green Open Space is one of the most important elements in an area to sustain the lives and activities of the people in that area. Basically, the Green Open Space is a natural element that has an important role in realizing the environmentally Denpasar city. As part of the spatial plan, the position of the Green Open Space Area will be a determinant of the living environment balance and other environments because the Green Open Space (GOS) is the lungs in an area. The Green Open Space Plan (GOS) is the basis for anticipating the rapid development of investment in a particular area, which must be followed by a policy for the provision of Green Open Space. The land limitation causes the existence of Green Open Space to be reduced because it is urged by other functions that arise along with the need for 
investment in an area. Green Open Space Area often experience land conversion into buildings or hardened land, from this, the plant is not possible to grow. In addition, local government is not also consistent in maintaining the existing Green Open Space, due to the many functions of land conversion, widening or development of roads that are not balanced with the rejuvenation of the Green Open Space. This makes the Green Open Space Area required to compete with the situation in Denpasar City, which focuses on tourism development to increase regional income in the form of investment.

The legal issues related to the stipulation of Denpasar City Spatial Plan by the regional government as a green open space area, especially in Denpasar City Region are actually not new legal phenomena. The problem is always actual to be studied in order to find an alternative solution to the problem. The local dissatisfaction is often ignored by region government by on behalf of the creation of development, public interest, and people welfare. As a result, violation by violation that arises is as a form of active resistance from the people in realizing a physical development either a non-permanent or permanent building in a green open space that has been determined by the region government and actually strictly forbidden by the region government to establish a building.

Here the role of region government should pay attention to the legal principle of investment, those are: 1) International law principle, it is an investment law that should pay attention to investment values that apply in international world, 2) Economic democracy principle, is the investment can be done freely and openly, especially for foreign investors, this principle is important because it supports the existence of a free market and 3) utilization principle, it is the return om investment be used for public welfare. Considering how important it is to pay attention to many complaints and expectations of the people, especially for those whose private land is exposed to the effect of the regulations issued by the Regional Government, especially the green open space, thus the in-depth study in this research answer the problem. Related to this study, some studies have been conducted previously such as in [1] which conduct a study about Legal Protection and Guidance for Street Vendors in Balikpapan. This study aimed to analyze why the street vendors should get legal protection and guidance of the Government and to analyze how policies Balikpapan City Government in the handling and coaching the street vendors in Balikpapan. The results of this study reveals that in the constitutional rights of citizens to choose an occupation guaranteed by the state in accordance with Article 27 paragraph (2) of Constitution 1945, states "Every citizen has the right to work and a decent living for humanity. Article 13 of Law Number 9 Year 1995 regarding Small Business, stated the Government shall foster a business climate in the aspect of protection, by establishing regulations and policies. in the Balikpapan City, it is needed to establish regional regulations governing the Management and Development of street vendors. Moreover, in [3] analyzed the challenges to traditional markets amid the influence of globalization and trade liberalization; and the legal protection for traditional markets in the era of trade liberalization. Her finding showed that challenge to traditional market in the middle of globalization influence and trade liberalization is marked by the influx of investment flows in Indonesia which has swept the whole field of investment from one region to another most lucrative area, Legal Protection For Traditional Market in Liberalization Era Trafficking in views in Presidential Regulation No. RI. 112 of 2007, Regulation of the Minister of Trade No. RI. 56 / M-DAG / PER / 9/2014, and the Regulation of the Minister of Home Affairs of the Republic of Indonesia No. 20 of 2012. Based on the background above, thus the purpose of this study is to find out and to figure out the form of legal rotection for the People of Denpasar City whose land is exposed to the Green Open Space and thr procedures are given by Denpasar City Government to the people whose land is exposed to the Open Space Green in investing. 


\section{Methods}

This study applied the qualitative method. The empirical legal research or called as sociological legal research is used as the approach of this study. In collecting the data, the researcher conducted the data by using observation and interview. The population of data is the citizens whose land is exposed to Green Open Space Areas in Denpasar city. Furthermore, this study is conducted in Denpasar city, Province of Bali.

\section{Results And Discussion}

Building on the purpose of the study to figure out the form of legal protection for citizens whose land is exposed to Green Open Space Areas in Denpasar city and the economic rights granted by Denpasar City Government to the citizens whose land is exposed to the Green Open Space Area, thus the results of this study are discussed in the following description.

\subsection{Form of Legal Protection for People of Denpasar City Whose Land is Exposed to Green Open Space Area}

The essence of legal protection cannot be separated by prioritizing human rights, that is, with the presence of the state in assisting the people when people experience problems in continuing their lives. The law can effectively carry out its function to protect the interests of society if it is upheld. The keyword in legal protection is the presence of legal enforcers such as the police, prosecutor, judge and lawyer in assisting people who exposed to legal issues. In other words, legal protection can be realized if the law enforcement process is also carried out properly and correctly by not forgetting and heeding human rights. The process of law enforcement is one of an effort to make law as a guideline in every behaviour of the people, apparatus or the law enforcement institution.

In connection with this research, is how Denpasar City Government on its own initiative tried to provide assistance such as compensation money to the people of Denpasar City whose land is exposed to the Green Open Space, especially land that was privately owned by way of hereditary ownership. This is considered very reasonable because the economic value of land exposed to the Green Open Space is relatively low in value. Indeed, if viewed from the side of the tourism industry, this is certainly very beneficial for region government, considering the people will be delighted to enjoy the green view along the way so that it contributes to the revenue of Denpasar City Government. However, if examined more deeply from the side of the landowner, so what was happened otherwise. The private landowner exposed to the Green Open Area will not be able to cultivate their land by leasing land or selling their land for other development purposes. From the problems arise, it is necessary to have a policy that needs to be implemented so that it can develop investment flows especially in the economic sector, both sustainably and efficiently for the people who are economical. Therefore, the region governments should pay attention to the principles of investment law, they are: 1) the principle of international law, which means that investment law must pay attention to the values that apply in the international world in order to create world economic growth, 2) the principle of economic democracy, which means that investor in this case as investors, can be done freely and openly for foreign investors, this principle becomes important because to support the existence of a world free market, 3) the principle of utilization, which means that with the 
existence of these investors, the result of the capital investment can be used for the welfare of the wider society.

Denpasar City is the capital of the Province of Bali. Denpasar is the largest city in Southeast Nusa Island and the second-largest city in Eastern Indonesia region after Makassar. The growth of the industry in the field of tourism in Bali Island urged Denpasar City into a centre of business activity and placed this city as an area that has high per capita income and growth in the Province of Bali. The area of Denpasar City has a land area of 12,778 Ha, administratively divided into four sub-district territories they are twenty-seven villages and sixteen urban villages. The rules should be the commander and not be degraded. The week of the institution in upholding the regulations, especially accompanied by omission will lead to violation of spatial planning. The indications of violation have been felt especially in the border areas of the city with the district. The boundary of green open space that has been knocked on the hammer, in fact, used for building the various functions. This omission will set a bad precedent in future development. The future issues in spatial planning are not only at the level of the people and the government but also between the government and the private sector and even with the government.

Theoretically, the understanding of open space is a space that consists of hard space limited by the architectural walls and is used for social activity and soft space is dominated by the natural environments such as garden, green belt and parks [4]. Green Open Space of the city is a part of open spaces of an urban area filled with plants and various other types of vegetation. The diversity of vegetation produces different levels of vegetation density in an area depending on land use. The vegetation density in Denpasar City greatly affects the surface temperature which will create a level of greenness and coolness of the city. The high and low density of vegetation can be determined by using the Vegetation Index Data Analysis technique through Remote Sensing technology. From the description above, if seen the benefits from the creation of a green open space of Denpasar City, it can be identified as the lungs of Denpasar city; as the place for people recreation, the place like this can be seen in some places like Lumintang field and Puputan Badung field in front of Jagat Nata Temple in Denpasar, which is crowded in the morning and in the afternoon by the people for sport or just recreation and gathering with family; as a water catchment area; as one of the instruments in order to beautify the face of Denpasar; and as a medium to absorb air pollution.

Talking about legal protection for citizens whose lands are exposed to green open space, the appropriate theory for analyzing this problem is the theory of authority. The essence of the authority theory in this research is all kinds of rights and obligations attached to the Government of Denpasar city in regulating the people in order to realize shared welfare fairly and evenly based on Human Rights.

\subsection{Legal Protection Provided by the Government of Denpasar City to Citizens Whose Land is Exposed to Green Open Space Area in Investing}

In analyzing problems related to the economic rights of citizens whose land is exposed to green open space, the relevant theory to be used in analyzing is the theory of the welfare state law. The essence of the theory of welfare state law is that the state is responsible for the welfare of its people. In other words, every policy issued by the government or state ideally purposeful and useful to improve the welfare of the people fairly and evenly. The antithesis of this theory relates to the policy of the Denpasar City Government to issue a regulation on Green Open Space, if it turns out to cause inconvenience or poverty for the citizens whose exposed, it must be proportionally and professionally to be observed again. Thus the principle 
of law enforcement for the welfare of the people becomes relevant and well applied in the form of published regulations.

Investment is a component of the Gross Domestic Product with a certain formula. The investment function in this aspect is divided into non-residential investment (such as factory and machinery) and residential investment (new homes). Investment is a function of income and interest rates, seen in relation to it. An increase in income will encourage greater investment, which a higher interest rate will reduce the interest in investment as it will be more expensive than lending money. Although, if another company chooses to use its own funds for investment, the interest rate represents an opportunity cost of investing from those funds rather than lending to get interested. If viewed from various types of investment, the outlines include land investment, education investment, stock investment, foreign currency investment, it is expected that investors will have the profits from the strengthening exchange rate of foreign currency against rupiah.

So far the Regional Government in Denpasar City has never had the policy to free its people to pay land taxes. In fact, in areas exposed to land consolidation, the land tax must be paid high. Tax officers can be from house to house to collect tax on behalf of regional income and people welfare. The giving of incentives by Denpasar City Government to citizens whose lands were exposed to green open space until this research was carried out seems to have never been done.

To develop investment prospect in Denpasar city there are the references that is held based on the principles of legal certainty, it means that investors must be based on applicable laws, those are: firstly, the principle of openness, it means that the people have the rights to get true and honest information about the applicable investment; second, the principle of accountability, it means that all the results can be responsible to the people; the third, the principle of equal treatment, it means that investors must take the same treatment of investors (foreign or not) except in matters of state security; the fourth, the principle of togetherness, it means that with a common goal towards the people's welfare; the fifth, the principle of fair efficiency, it means that achieving a business climate that is fair, conducive, and healthy competitiveness; the sixth, the principle of sustainable, it means that there must be a planning to provide welfare in the present and in the future; the seventh, the principle of environmental insight, it means that investment must maintain environmental sustainability; the eighth, the principle of independence, it means that investors must prioritize the potential of the State; and the last, the principle of balance of progress and national economic unity.

In attracting the interest of the people to travel to Denpasar city, then environmental management is crucial to be implemented. One form of this environmental arrangement is by implementing green open space in Denpasar City. Based on the research conducted, evidently, the determination of green open space has an unfavourable impact on the investment climate, especially in the green open space area that is set on Jalan Ahmad Yani, Jalan Cikomaria, Jalan Astasura, Jalan Ngurah Rai bypass which included as Denpasar City Region. The arrangement of Jalan Ahmad Yani Utara area, especially in Peguyangan Village is very uncomfortable and tends to be chaotic. The announcement board of green open space assembled by Denpasar City Government is one by one being removed by irresponsible persons, so that as if the area is not green open space. In addition, there is a building which is actually built next to a placard about the area of green open space. From these problems, the policies adopted resulted in disruption of investment lines in Bali, especially in Denpasar city in developing a flow of sustainable investment and efficient for economical people. 


\section{Conclusions}

The form of legal protection obtained by landowners exposed to green open space in reality that obtained is only a socialization and guidance in order the citizens are advised not to sell or lease their land to investors and Investment Rights granted by Denpasar City Government to citizens whose land is exposed to green open space until this study was completed, it still did not exist. Denpasar City Government only determines it based on the study that has been established by a team formed specifically for that.

\section{References}

[1] M. S. Pulungan, "Perlindungan Hukum dan Pembinaan Pedagang Kaki Lima di Balikpapan," $J$. Matra Pembaruan, vol. 1, no. 1, pp. 75-84, 2017.

[2] "Constitution," 1945.

[3] N. K. D. Dewi, "Perlindungan Hukum Terhadap Pasar Tradisional Di Era Liberalisasi Perdagangan," Law Reform, vol. 14, no. 1, p. 1, 2018.

[4] R. Trancik, Finding Lost Space: Theories of Urban Design. New York: Van Nostrand Reinhold Company, 1986. 